\title{
Integral valuation of investment potential in terms of economy digitalization
}

\author{
Diliara Rasimovna Abdrakhmanova \\ Institute of Management, Economics and Finance \\ Kazan federal university \\ Kazan, Russian Federation \\ azat90@yandex.ru
}

\author{
Anna Anatolevna Ibatullina \\ Institute of Management, Economics and Finance \\ Kazan federal university \\ Kazan, Russian Federation \\ anna_pigasova@mail.ru
}

\author{
Olga Vladimirovna Pachkova \\ Institute of Management, Economics and Finance \\ Kazan federal university \\ Kazan, Russian Federation \\ olga_pachkova@mail.ru
}

\begin{abstract}
Modern economy digitalization conditions require new tools of countries/regions investment appraisal. The link between informatization and innovation of the digital society, the opportunity to invest in it can hardly be overestimated. Despite the fact that there is a global innovation index, a doing business index, a global competitiveness index, etc., none of them provides a comprehensive assessment of the investing possibility. This issue is acute in the digital environment. The relevance of this work is derived by the lack of the country/region investment index methodology which has full investment potential information.

The article describes the formation algorithm and calculates the integral valuation of the countries-indicators investment potential which is based on the "7I Concept" proposed by the authors. It joins infrastructure, innovation, information accessibility, intellectual resources, institutional environment and justifies the use of the official statistics. Selected indicators are key in assessing the investment eventuality in digitalization terms. The main goal of this article is the countries-indicators method development which can be used in various fields of state international and domestic policy. In the different industries digitalization process it is important to monitor which industries (financial, military-industrial sector, garment industry, staple industry, etc.) are attractive to invest more. It is universal for finding the integral indicator from the variety of indicators selected by unrelated and related features.
\end{abstract}

The algorithm of countries-indicators sampling and the use of the "7I Concept" is based on the authors' results obtained in previous studies.

Keywords - digitalization, investment evaluation, countriesindicators

\section{INTRODUCTION}

The high potential of the information technology industry in Russia and the need for transition to the digital economy are widely discussed in modern society (Russia is the 45th among 166 countries). Digitalization has become not only a key technological trend but also a catalyst for global transformation in society. Russia's integration into the world economic space and the expansion of international relations determine the need to develop various indicators to highlight the competitive advantages of a country or a group of countries in a region in the light of global cooperation in order to attract investment.

Assessment of the national economy position in a number of countries is based on the use of various international rankings. Each ranking is based on a methodology adopted / developed by the international organization that publishes periodic reports on its statistical studies.

A country ranking is an ordered list of countries by a specific criterion or group of criteria. The relevance of the rankings is determined by their inclusion in the development targets of Russia and its regions.

The purpose of the monitoring system creation is providing information and analytical support for the policy of federal and regional public authorities of the national economy transition to the trajectory of new information economic growth. The monitoring tasks set by digitalization consist in the organization of targets and benchmarks of the Russian Federation conceptual and policy documents regular measurement in the field of investment climate, methodically compatible with international standards and recommendations of international organizations.

In world practice a number of indices are used to measure the degree of countries readiness for a new type economic growth. The integral criterion is the resulting composite index, composed of quantitative and qualitative indicators obtained on the basis of the observed World Bank statistics [16] and others international organizations (such as International 
Telecommunication Union). The use of these data is determined by the fact that they are collected on the basis of a unified methodology, they are differed by the strict periodicity that allows one to obtain dynamic dependencies and build reliable forecasts.

\section{PROBLEM STATEMENT}

The article considers possibility of regions' independent ratings application for an assessment of region management efficiency [3]. New institutional indices are derived from Russian enterprise surveys held under the BEEPS project of the European Bank of Reconstruction and Development [2].

The growth of the regional gross product is determined by the investments in physical and human capital. Regional investment attractiveness exists in an unstable and risky environment [10].

The regions differ by the labor, financial, natural and other resources, as well as by various conditions created for investors by the governing bodies. The authors of the article provide the results of a number of different methods analysis for assessing investment potential and indicate the main advantages and disadvantages of existing approaches and methods of evaluation that is particularly relevant and necessary for investors [4].

Investments can be considered as an indicator of the socioeconomic development of a region. It is important to prevent the disparity between the achieved level of investment in the economy and the level that ensures sustainable development of the region. This purpose can be achieved by providing an adequate quantitative assessment of the investment activity in the region [11]. Special attention is paid to the process of weighing investment attractiveness factors. This process is one of the key stages of the assessment, and the accuracy of such weighing influences the quality of the integral regional investment attractiveness index [12].

The article pays particular attention to the tasks of improving regional innovative policy aimed at creating of the conditions for the formation and expanded reproduction of full-cycle innovation, involvement the business sector in the innovation processes, and the correlation between the regions innovation and socio-economic policies. At the same time, on the base of the other countries experience, particular China and Brazil, it is possible to solve the problems of the science development and increase the innovative activity of the national enterprises using the open markets [5].

The problems of investment attractiveness of regions, the main approaches and methods of its evaluation in terms of the economy digitalization are considered in the article. The investment attractiveness valuation is compounded by a variety of existing methods with insufficient elaboration. The formation of the assessing and monitoring system of the region investment attractiveness is required for the development of system and effective management decisions and actions for the organizational support of the regions investment processes [1].
The history of countries (regions) investment attractiveness valuations counts more than forty years. One of the first is the technique of Harvard business school, according to which the first studies were carried out in 1969. According to this technique, the legislative conditions for foreign and national investors, the possibility of capital exportation, the national currency state, political situation in the country or in a particular region, the inflation level as well as the possibility of using national capital were evaluated by the expert method.

\section{RESEARCH QUESTIONS}

The research problem is caused by the following facts:

1) The variety of heterogeneous factors affecting the investment potential of the country, such as: information, innovation, intelligence, institutions, infrastructure. Each subindex separately evaluates a specific group of factors.

2) The need to process large data sets for the countries of the world (about 190 countries), which leads to large time and financial expenditures and makes it difficult to understand findings.

3) The lack of the integral index of investment potential valuation and accepted methodology of the countriesindicators sampling that is typical for the countries selected groups, on the basis of published statistics.

\section{PURPOSE OF THE STUdY}

According to the Global Competitiveness Index 2017-2018 of the World Economic Forum (WEF), Russia is 38th among 137 countries. Accelerated digitalization significantly contributed to the fact that the country rose by five lines in the ranking compared to last year. Higher education and training (32nd place), technological readiness (57th place) and innovation (49th place) are among the key pillars determining the position of Russia in the ranking. These data predetermined the research purpose, which is to develop a methodology of valuation the investment potential in the conditions of digitalization on the basis of countriesindicators. Figure 01 shows the dynamics of Russia's global competitiveness Index for 2008-2018.

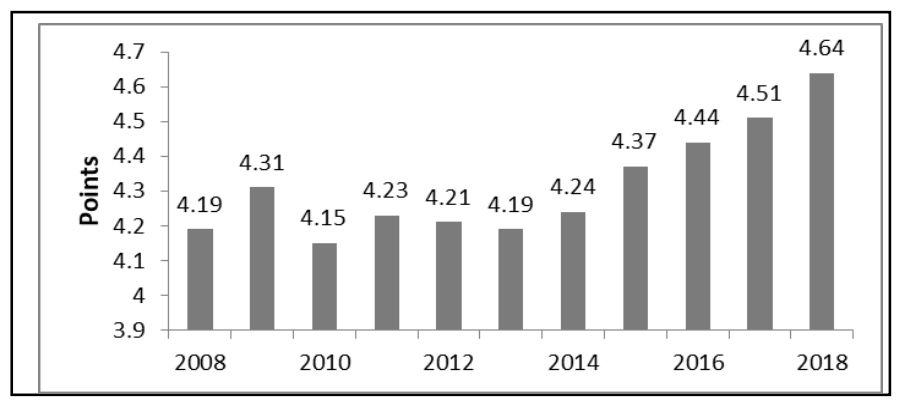

Fig. 1. Dynamic of Russia’s Global Competitiveness Index

\section{RESEARCH METHODS}

General and specific research methods were used in the research: 
1) On the basis of correlation pleiades method, the countries-indicators were determined in each study group. Correlation pleiades is the method of displaying information about correlations which allows one to structure them and combine correlation factors.

The kernel (indicator) is interpreted as the basic object that defines the behavior of all objects in the group. By the nature of its parameters dynamics it is possible to estimate the changes that occur with the other objects parameters of this group. Such hypothesis makes it possible to analyze not all the set of objects that characterize the group, but only the kernel object. It significantly simplifies the implementation of classification procedures and algorithms.

The sample of countries is determined on the basis of the research results conducted in 2011-2017. In this research, an indicator-country refers to the choice by means of correlation pleiades of one country from the investment and innovation region (pleiades), which is at the top of the rankings associated with information technology, innovation, intelligence, institutions, infrastructure.

As a result of the correlation pleiades procedure use, five pleiades of national economies with similar parameters of economic growth and the kernels of these pleiades were identified:

1 Pleiad: 16 European national economies - France is a country-indicator;

2 Pleiad: 8 European national economies - Estonia is a country-indicator;

3 Pleiad: 9 national economies - former USSR republic Russia is a country-indicator;

4 Pleiad: 9 East Asia \& Pacific (EAS) \& South Asia (SAS) national economies - Malaysia is a country-indicator;

5 Pleiad: USA, UK, Canada - USA is a country-indicator.

The application of the correlation pleiades method significantly simplifies the research and the parameters analysis of a large number of countries is replaced by the analysis of indicator countries. In our case, 5 national economies - France, Estonia, Russia, Malaysia and USA - are the centers that determine 45 countries [Kirshin et al., 2016].

2) The 7I concept allows allocating groups of factors which most fully characterize investment potential of the country in the conditions of digitalization (in this work: information, innovations, infrastructure, intelligence, institutes).

Each group of factors "7I Concept" perform the following basic functions:

- Information - the basis of intellectual (creative) economic activity.

- Intelligence - the carrier and creator of new information.

- Information and intelligence together perform a selective function of sampling innovations that are included in the "information" and "intelligence"in this research.
- Institutions form the legal framework and traditions.

Infrastructure performs supporting and bonding functions.

- Investments - the function of financial support of the entire system "7I", in this research we give a comprehensive assessment of this factor [7].

3) The method of competitiveness analysis of Klaus Schwab and Xavier Sala-I-Martin (Xavier Sala-I-Martin) allows aggregating the selected groups of observed indicators [15].

The maximum and minimum values were calculated for the analyzed groups of indicators.

Then the aggregated indicators were calculated according to the following method.

(X_i - x_min) $/\left(x \_m a x-x \_m i n\right)$

"(1)" is for indicators whose values have a positive impact on attracting foreign investment.

(X_max-x_i) $/\left(x \_m a x-x \_m i n\right)$

"(2)" is for indicators whose values have a negative impact on attracting foreign investment;

where $x i$ is the indicator value for a given country,

x_min and $\mathrm{x} \_$max - minimum and maximum values of the indicator in the period among all the studied countries,

i - number of indicators.

4. In the applied research the comparative method is used as the main in classification, typology, evaluation, generalization. It allows separating general and distinctive features and properties of studied objects and their development processes.

Successful application of the comparative method implies unification of observation ways including standardization of initial data and obtained results [10].

\section{FINDINGS}

On the basis of the proposed methodology, the structure of the integrated investment index was obtained (Table 1). 
TABLE I. THE STRUCTURE OF THE INTEGRATED INVESTMENT INDEX

\begin{tabular}{|c|c|c|}
\hline Sub- & Observed values & Ratio \\
\hline \multirow{10}{*}{$\begin{array}{l}\stackrel{0}{\Xi} \\
己 \\
\Xi \\
\Xi \\
\Xi \\
\Xi \\
\Xi \\
\Xi\end{array}$} & Air transport, freight (million ton-km) & \multirow[t]{10}{*}{0.15} \\
\hline & Air transport, passengers carried & \\
\hline & Air transport, registered carrier departures worldwide & \\
\hline & Rail lines (total route-km) & \\
\hline & Railways, goods transported (million ton-km) & \\
\hline & Railways, passengers carried (million passenger-km) & \\
\hline & Transport services (\% of commercial service exports) & \\
\hline & Transport services (\% of commercial service imports) & \\
\hline & Transport services (\% of service exports, BoP) & \\
\hline & Transport services (\% of service imports, BoP) & \\
\hline \multirow{9}{*}{ 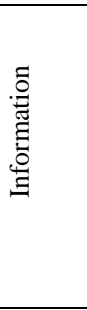 } & Fixed broadband subscriptions & \multirow[t]{9}{*}{0.15} \\
\hline & Fixed broadband subscriptions (per 100 people) & \\
\hline & Fixed telephone subscriptions & \\
\hline & Fixed telephone subscriptions (per 100 people) & \\
\hline & Internet users (per 100 people) & \\
\hline & Mobile cellular subscriptions & \\
\hline & Mobile cellular subscriptions (per 100 people) & \\
\hline & Secure Internet servers & \\
\hline & Secure Internet servers (per 1 million people) & \\
\hline \multirow{17}{*}{ 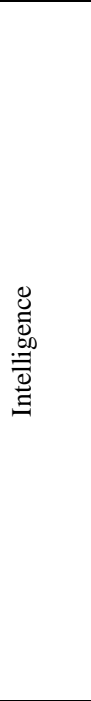 } & $\begin{array}{l}\text { Communications, computer, etc. (\% of service exports, } \\
\text { BoP) }\end{array}$ & \multirow[t]{17}{*}{0.35} \\
\hline & $\begin{array}{l}\text { Communications, computer, etc. (\% of service imports, } \\
\text { BoP) }\end{array}$ & \\
\hline & $\begin{array}{l}\text { Computer, communications and other services ( } \% \text { of } \\
\text { commercial service exports) }\end{array}$ & \\
\hline & $\begin{array}{l}\text { Computer, communications and other services (\% of } \\
\text { commercial service imports) }\end{array}$ & \\
\hline & Gross enrollment ratio, primary, both sexes $(\%)$ & \\
\hline & Gross enrolment ratio, pre-primary, both sexes (\%) & \\
\hline & Gross enrolment ratio, secondary, both sexes (\%) & \\
\hline & Gross enrolment ratio, tertiary, both sexes $(\%)$ & \\
\hline & High-technology exports (\% of manufactured exports) & \\
\hline & High-technology exports (current US\$) & \\
\hline & ICT goods exports (\% of total goods exports) & \\
\hline & ICT goods imports (\% total goods imports) & \\
\hline & ICT service exports (\% of service exports, BoP) & \\
\hline & ICT service exports (BoP, current US\$) & \\
\hline & Research and development expenditure (\% of GDP) & \\
\hline & Researchers in R\&D (per million people) & \\
\hline & Scientific and technical journal articles & \\
\hline \multirow{3}{*}{ 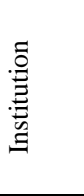 } & $\begin{array}{l}\text { Cost of business start-up procedures (\% of GNI per } \\
\text { capita) }\end{array}$ & \multirow[t]{3}{*}{0.25} \\
\hline & $\begin{array}{l}\text { Cost of business start-up procedures, female (\% of GNI } \\
\text { per capita) }\end{array}$ & \\
\hline & $\begin{array}{l}\text { Cost of business start-up procedures, male (\% of GNI per } \\
\text { capita) }\end{array}$ & \\
\hline
\end{tabular}

\begin{tabular}{|l|l|}
\hline GDP (current US\$) \\
\cline { 2 - 2 } & GNI (current US\$) \\
\hline Labor force, total \\
\cline { 2 - 2 } Patent applications, nonresidents \\
\hline Patent applications, residents \\
\hline Population, total \\
\hline Start-up procedures to register a business (number) \\
\hline $\begin{array}{l}\text { Start-up procedures to register a business, female } \\
\text { (number) }\end{array}$ \\
\hline Start-up procedures to register a business, male (number) \\
\hline $\begin{array}{l}\text { Unemployment, total (\% of total labor force) (modeled } \\
\text { ILO estimate) }\end{array}$ \\
\hline $\begin{array}{l}\text { Unemployment, total (\% of total labor force) (national } \\
\text { estimate) }\end{array}$ \\
\hline
\end{tabular}

The obtained integral investment index is presented in figure 1. Based on the figure, it can be concluded that the most attractive investment climate among the selected pleiades is the pleiades of the United States, then France (Europe) and only then the Russian Federation (former Soviet republics). In order to determine the reasons that have influenced the decline in investment potential, it is necessary to continue this research in the framework of the following scientific works. Drawing the diagram of investment index dynamic (figure 2), the authors achieved the main goal of this research, namely developed the tool to value the investment eventuality in terms of the economy digitalization.

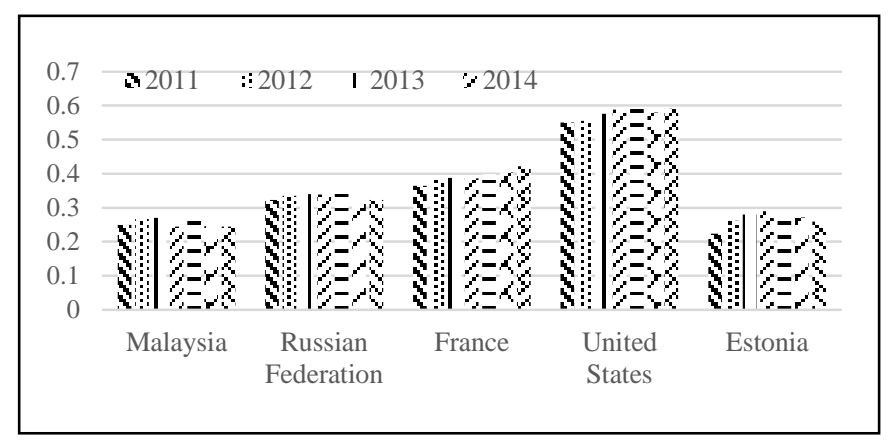

Fig. 2. Dynamics of the investment index in countries-indicators for 20112017

For the visualization, the results are presented by the graph (Figure 3). 


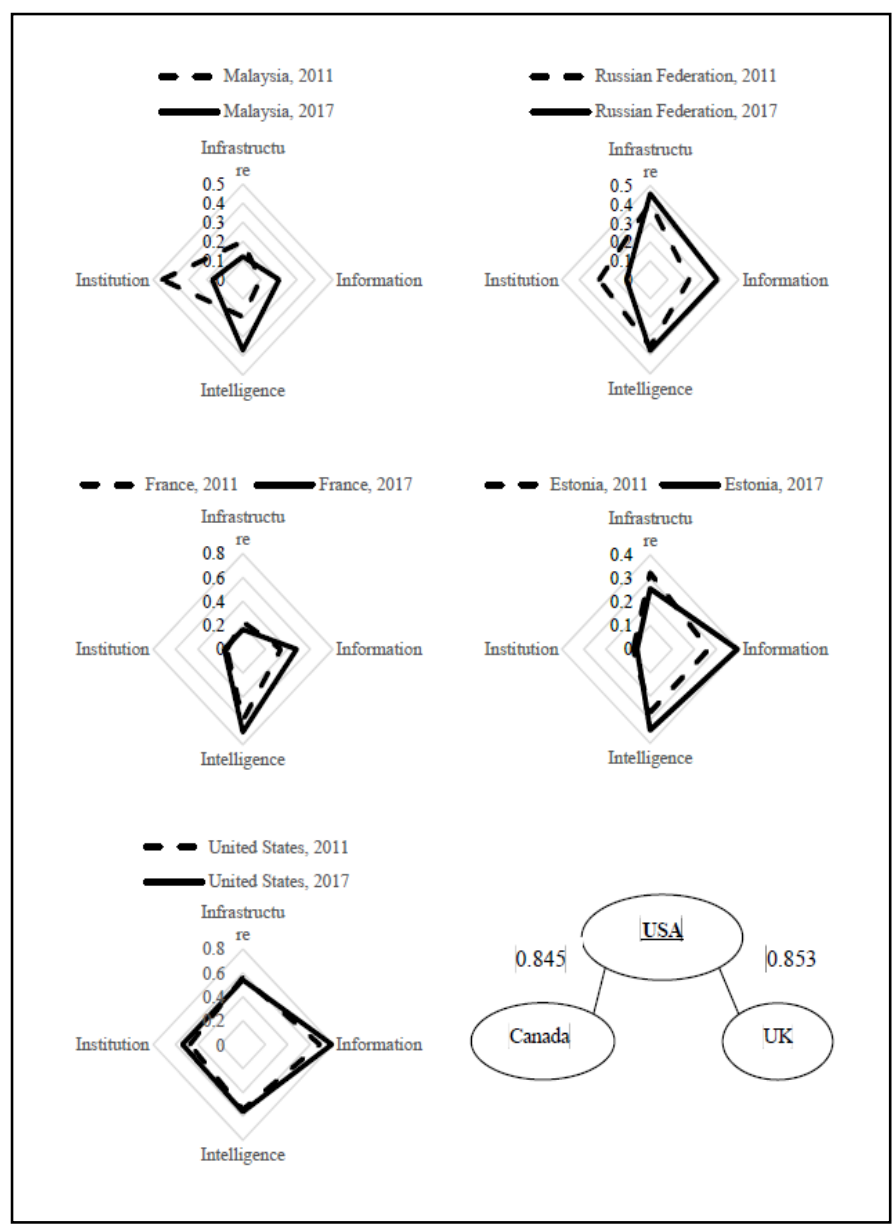

Fig. 3. Investment index in the countries-indicators for 2011-2017

\section{CONCLUSION}

The successful application of the developed method of countries-indicators involves the unification of the observation ways, including the standardization of the original data and the obtained results. The algorithm of the investigation is described below.

1) Based on the correlation pleiades method, the countries-indicators are determined in each study group [8].

2) The 7I concept allows one to allocate groups of the international indexes which most fully characterize new economic growth (in this work, it is innovative and investment growth on the basis of development of information and communication technologies, taking into account formation of institutional and infrastructural environment in the digitalization conditions) [7].

3) The methodology of K. Schwab's competitiveness analysis allows aggregating the selected groups of indicators.

4) The correlation and regression analysis establishes the relationship between the GNI (gross national income per capita) and the calculated indices.

The article uses a complex method of research, which is based on the results of previous works of the authors. This method of the integral index calculation can be used to assess the potential of different groups of countries and regions. Further there is a plan to extend this methodology to assess the Federal districts and subjects of the Russian Federation for determining the readiness of regions to the economy digitalization.

\section{Acknowledgment}

This work was funded by the subsidy allocated to Kazan Federal University for the state assignment in the sphere of scientific activities. And personally Doctor of Economics, Professor I.A. Kirshin.

\section{References}

[1] L.G. Akhtarieva, «Modern approaches to assessing the investment attractiveness of the regions,» USOTU Bulletin, Science, Education, Economy, vol. 1 (7), pp. 233-239, 2014.

[2] A. Baranov, E. Malkov, L. Polishchuk, M. Rochlitz, G. Syunyaev, «How (not) to measure Russian regional institutions», Russian Journal of Economics, pp. 154-181, 2015.

[3] I. Bondarenko, «Ratings of investment appeal of regions of Russia as a tool of assessment of region management efficiency,» Economics, 1, pp. 37-44, 2016.

[4] I. Golaydo1, Y. Soboleva, «Assessment and Management of Factors of the Regional Investment Potential,» Asian Social Science, 7, 2015.

[5] I.M. Golova, A.F. Sukhovey, «The problems and threats of innovative development of Russian regions,» Economy of the region, Retrieved from: http://www.economyofregion.com

[6] I.A. Kirshin, M.D. Mironova, O.V. Pachkova, «Index Assessment of Readiness of the Countries of BRICS Group for Information Society,» Procedia Economics and Finance, pp. 318-321, 2015.

[7] I.A. Kirshin, O.V. Pachkova, «Specification of System Object of State Regulation in the Information Russian Society,» Asian Social Sciences, 11 , pp. 501-506, 2015

[8] I.A. Kirshin, O.V. Pachkova, A. Melnik, «National economic dynamics typology on the basis of correlation pleiades method,» 3rd International Multidisciplinary Scientific Conference on Social Sciences and Arts, pp. 433-440, DOI: 10.5593/SGEMSOCIAL2016/B23/S06.055/, 2016.

[9] G.P. Luzin, «Theoretical and methodological aspects of assessing the investment attractiveness of the regions,» Institute of Economic Problems. Retrieved from [http://isei-konf2014.ucoz.ru/_ld/0/34].

[10] L. Nikolova, E. Plotnikova, «11th Global Conference on Sustainable Manufacturing - Innovative Solutions,» Berlin, pp. 159-164, 2016.

[11] E. Oleinik, A. Zakharova, «Evaluation of the Major Factors of the Region's Investment Activity Indian Journal of Science and Technology», Vol 9(36), DOI: 10.17485/ijst/2016/v9i36/102025, 2016.

[12] A. Pakhalov, «Methodological aspects of assessing regional investment attractiveness», Global Markets and Financial Engineering, 1(1). Retrieved from [http://dx.doi.org/10.18334/gmfe.1.1.276].

[13] The State Program of the Russian Federation "Information Society (2011-2020)" (approved by the decree of the Government of the Russian Federation No. 1815-r of October 20, 2010), etc.

[14] The concept of long-term social and economic development of the Russian Federation for the period until 2020 (KDR-2020), approved by the RF Government on November 17, 2008, No. 1662-r.

[15] Schwab's Competitiveness Analysis Technique. URL: http://www.weforum.org.

[16] The World Bank. URL: http://databank.worldbank.org 